Edited Mar 14

\title{
Microbial Ligand Coordination: Consideration of Biological Significance
}

Stephen D. Springer and Alison Butler*

Department of Chemistry and Biochemistry

University of California

Santa Barbara, CA 93106-9510

*Corresponding author (805) 893-8178; butler@ chem.usb.edu

\begin{abstract}
Siderophores are generally considered to be microbial chelating compounds secreted by bacteria to facilitate uptake of iron(III). Certain siderophores, however, have a high affinity for other transition metal ions, including manganese(III), copper(II), molybdenum(VI), and vanadium(V). A new class of microbial ligands produced by methanotrophs, called chalkophores, is produced to facility copper uptake. This review considers the coordination of siderophores to $\mathrm{Mn}(\mathrm{III}), \mathrm{Cu}(\mathrm{II} / \mathrm{I}), \mathrm{Mo}(\mathrm{VI})$ and $\mathrm{V}(\mathrm{V})$, and their stability constants relative to $\mathrm{Fe}(\mathrm{III})$, when available, as well as the coordination complexes of chalkophores to $\mathrm{Cu}(\mathrm{I})$.
\end{abstract}

Keywords: Siderophore, Iron, Manganese, Copper, Molybdenum, Vanadium 


\section{Edited Mar 14}

1. Introduction

2. Manganese Complexation by Siderophores

2.1. Desferrioxamine Siderophores

2.2. Pyoverdin-type Siderophores

2.3. Rhizoferrin

2.4. Protochelin

3. Copper Complexation by Chalkophores and Siderophores

3.1. Methanobactins

3.2. Yersiniabactin

4. Molybdenum and Vanadium Complexation by Siderophores

4.1. Protochelin and its Derivatives

4.2. Azotobactin

5. Summary

1. Introduction

Bacteria growing aerobically in a low iron environment, have evolved an iron(III) uptake strategy based on the secretion of chelating ligands that sequester and solubilize iron(III) from environmental iron oxides or directly from iron proteins in a host organism. These microbial ligands, termed siderophores, reflect the Greek root, sideros, for iron, and phore, for carrier. Along with siderophores, the producing bacterium expresses an outer membrane receptor protein that is specific for a particular siderophore and catalyzes the transport across the outer membrane. ABC-type transport proteins in Gram-negative bacteria direct the iron siderophore 


\section{Edited Mar 14}

complex through the periplasmic space and across the cytoplasmic membrane [1-4]. While Gram-positive bacteria lack an outer membrane and periplasm, the process of iron-siderophore import is still catalyzed by ABC-type transport proteins. Relatively recently a new ligand exchange mechanism of $\mathrm{Fe}(\mathrm{III})$-siderophore transport has been reported for the Gram-negative Aeromonas hydrophila [5] and the Gram-positive Bacillus cereus [6].

Many siderophore structures have been isolated and characterized from both Gramnegative and Gram-positive bacteria [7]. The common bidentate ligands within siderophores, include catechols, hydroxamic acids, and $\alpha$-hydroxy carboxylic acids, but coordination by other groups is well established also, including carboxylic acids, oxazolone, and thiazolidine groups, among others.

The stability of an iron(III)-siderophore complex is reflected in the significantly negative reduction potential, which in turn is consistent with the selectivity of siderophores for Fe(III) over Fe(II). The relationship between the reduction potential and the stability of the iron(III) complex is described by a modified Nernst equation (Equation 1), where $\mathrm{E}_{\text {aq }}^{\circ}$ is the reduction potential of free aqueous $\mathrm{Fe}^{3+}{ }_{(\mathrm{aq})}[8]$

$$
\mathrm{E}_{\mathrm{Sid}-\mathrm{FeIII} / \mathrm{II}}=\mathrm{E}_{\mathrm{aq}}^{\circ}-59.15 \log \left(\mathrm{K}_{\mathrm{f}}^{\mathrm{FeIII}} / \mathrm{K}_{\mathrm{f}}^{\mathrm{FeII}}\right)
$$

Thus, hexacoordinate Fe(III) complexation by most siderophores, and negative reduction potentials of these $\mathrm{Fe}(\mathrm{III})$-siderophore complexes mitigates against Fenton reactions and effectively controls the redox chemistry of iron(III) during uptake and transport [8].

Coordination chemists have been interested in the complexation of transition metal ions other than Fe(III) to siderophores since the initial discovery of siderophores [9-12]. Ga(III) and $\mathrm{Al}(\mathrm{III})$ are often used in place of Fe(III) to investigate complexation modes of siderophores by NMR. Lanthanide and actinide coordination to siderophores is established [13-15], although 


\section{Edited Mar 14}

possibly not of direct biological relevance. Chromium(III) complexes of siderophores are often prepared because the $\mathrm{d}^{3}$ electronic configuration dictates slow ligand substitution in an octahedral complex [16] and thus these complexes are useful to determine the fate of a metalsiderophore complex in the initial stages of microbial uptake, however $\mathrm{Cr}$ (III)-siderophores are not biologically relevant, and in fact toxic to bacteria [16]. Following the initial discovery of siderophores, many investigations with divalent transition metal ions have been carried out [17, 18], although these ions are generally displaced by $\mathrm{Fe}(\mathrm{III})$.

The focus of this review is recent investigations on complexation and transport of manganese, copper, molybdenum, and vanadium by siderophores and also chalkophores, which is a new microbial ligand class produced by methanogens and is specific for $\mathrm{Cu}(\mathrm{I})$. Along with iron and copper, manganese is an important micronutrient which many organisms use as a redox cofactor $[19,20]$. Bacteria have a variety of biological routes to obtain manganese, yet like iron, manganese is often found in the environment in oxide minerals composed of $\mathrm{Mn}$ (III) or $\mathrm{Mn}$ (IV) [21]; thus siderophore-mediated transport of $\mathrm{Mn}$ (III) could appear to be functionally similar to siderophore-mediated Fe(III) transport. Bacteria that fix dinitrogen have a high demand for iron, but most also a requirement for molybdenum to be incorporated in nitrogenase, or vanadium to be incorporated in the alternative nitrogenase [22]. A previous report suggested that siderophores could facilitate the uptake of molybdate into microbial cells[23], although without the use of a

radioactive isotope (e.g., ${ }^{99} \mathrm{Mo}$ ) or isotope ratio mass spectrometry (which was carried out later; see below), or even investigating transport- deficient mutants, siderophore-mediated uptake of metals other than Fe(III), had not been conclusively established, until recently.

2. Manganese Complexation by Siderophores 
Edited Mar 14

Manganese is abundant in surface waters of the Black Sea, where it is found at $\mu \mathrm{M}$ levels as $\mathrm{Mn}(\mathrm{III}) \mathrm{L}$ and fully complexed by a ligand or class of ligands, "L" [24, 25]. While the nature of the ligand(s) is not known, the ligation clearly stabilizes $\mathrm{Mn}$ (III) against disproportionation to $\mathrm{Mn}(\mathrm{II})$ and $\mathrm{MnO}_{2}$ [25]. Biological ligands such as siderophores can bind $\mathrm{Mn}(\mathrm{III})$, although most siderophores preferentially coordinate Fe(III), as shown by their overall higher stability constants. However, as described below, some siderophores have a higher affinity for $\mathrm{Mn}(\mathrm{III})$ over Fe(III).

\subsection{Desferrioxamine Siderophores}

Manganese(III) complexes of the linear and cyclic hydroxamate siderophores desferrioxamine B and E (DFOB and DFOE; Figure 1), respectively, were initially investigated as mimics of superoxide dismutase [26]. A green 1:1 complex of Mn(III)-DFOB ( $\lambda_{\max } 636 \mathrm{~nm}, \varepsilon$ $128 \mathrm{M}^{-1} \mathrm{~cm}^{-1}$ and $\left.310 \mathrm{~nm}, \varepsilon 2050 \mathrm{M}^{-1} \mathrm{~cm}^{-1}\right)$ and $\operatorname{Mn}(\mathrm{III})-\mathrm{DFOE}\left(\lambda_{\max } 600 \mathrm{~nm}, \varepsilon 106 \mathrm{M}^{-1} \mathrm{~cm}^{-1}\right.$ and $325 \mathrm{~nm}, \varepsilon 2560 \mathrm{M}^{-1} \mathrm{~cm}^{-1}$ ) forms quantitatively by air oxidation of $\mathrm{Mn}$ (II) in the presence of the siderophores, or by direct reaction of siderophores with $\mathrm{Mn}(\mathrm{OH})_{3}$ or $\mathrm{Mn}(\mathrm{OAc})_{3}$ [26]. Equimolar EDTA competes effectively for Mn(III) complexation from Mn(III)-DFOB (i.e., the linear siderophore), but not with $\mathrm{Mn}(\mathrm{III})$-DFOE (i.e., the cyclic siderophore). In the case of Mn(III)DFOE, a 5-fold excess of EDTA is required to sequester Mn(III) from Mn(III)-DFOE. While these $\mathrm{Mn}$ (III) siderophore complexes can catalyze the disproportionation of superoxide, they were less efficient than $\mathrm{Mn}^{2+}$ aq, and thus not efficient SOD mimics [26]. 


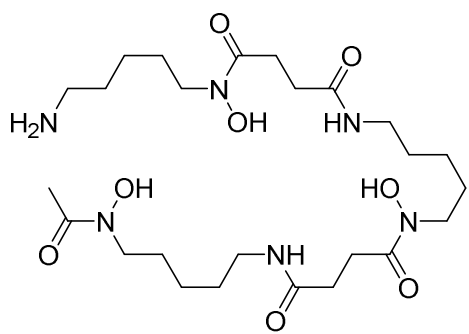

Desferrioxamine B (DFOB)

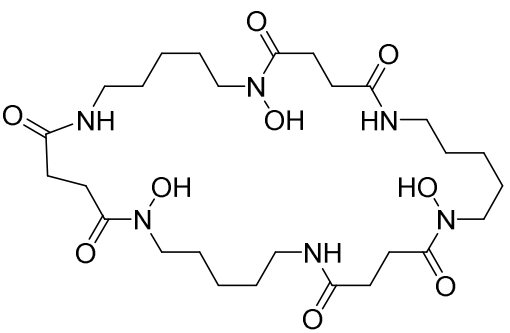

Desferrioxamine E (DFOE)

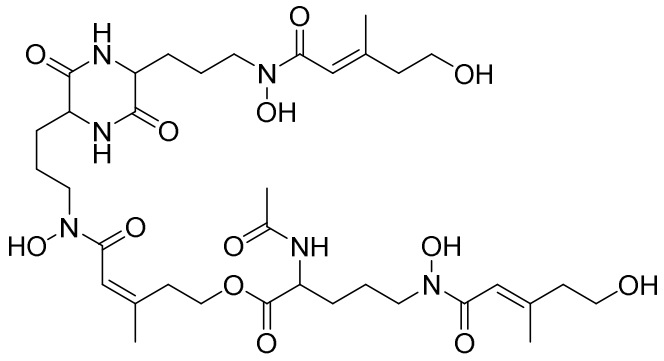

Coprogen

Figure 1: Selected hydroxamic acid siderophores.

The air oxidation of $\mathrm{Mn}(\mathrm{II})$ in aqueous solution is $\mathrm{pH}$ dependant and facilitated by ligand coordination. Above $\mathrm{pH} 7$, chelated $\mathrm{Mn}$ (II) is readily oxidized by dioxygen to $\mathrm{Mn}(\mathrm{III})$ [27], and the $\mathrm{Mn}(\mathrm{III})$ oxidation state is stabilized by the hard donor oxygen atoms of the hydroxamate ligands [28]. The rate of oxidation of the $\mathrm{Mn}(\mathrm{II})$-DFOB complexes by $\mathrm{O}_{2}$ is fastest for the fully deprotonated complex, $\mathrm{Mn}(\mathrm{II})-\mathrm{DFOB}^{-}$, and decreases with increasing state of protonation:

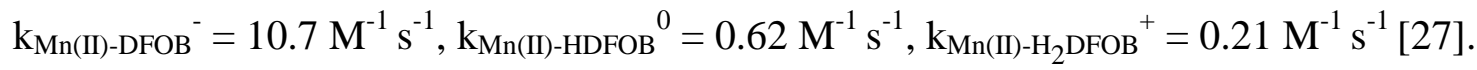

The stability constants of the Mn(II) complexes vary with the extent of complex protonation and are all relatively small (i.e., $\mathrm{Mn}(\mathrm{II})-\mathrm{DFOB}^{-}, \operatorname{logK}=8.8 \pm 0.5 ; \mathrm{Mn}(\mathrm{II})-\mathrm{HDFOB}^{\circ}$, $\left.\log \mathrm{K}=7.7 \pm 0.4 ; \mathrm{Mn}(\mathrm{II})-\mathrm{H}_{2} \mathrm{DFOB}^{+}, \log \mathrm{K}=5.7 \pm 0.4\right)$ compared with the $\mathrm{Mn}(\mathrm{III})$ complex, 
Edited Mar 14

$\mathrm{Mn}(\mathrm{III})-\mathrm{HDFOB}^{+}$at $\log \mathrm{K}=29.9 \pm 0.5$ [27]. The stability constant of this $\mathrm{Mn}(\mathrm{III})$ complex approaches that of $\mathrm{Fe}(\mathrm{III})$ at $\log \mathrm{K}=30.6$ [29]. The $\mathrm{Mn}(\mathrm{III})-\mathrm{HDFOB}^{+}$complex is stable from $\mathrm{pH}$ 7.1 to 11.3 [27]. Above $\mathrm{pH} 11.3 \mathrm{Mn}(\mathrm{III})-\mathrm{HDFOB}^{+}$disproportionates, forming a poorly crystalline birnessite precipitate $\left(\mathrm{MnO}_{2}\right)$ and $\mathrm{Mn}(\mathrm{II})-\mathrm{DFOB}^{-}$[27]. Below pH 7.1 the complex irreversibly decomposes via intermolecular electron transfer, resulting in Mn(II) and oxidized ligand fragments in the 200-400 mass unit range, consistent with hydrolytic cleavage of desferrioxamines, although the specific fragments were not characterized further [27].

Duckworth and Sposito have probed the coordination geometry of Mn(III)-HDFOB ${ }^{+}$ complexes as a function of $\mathrm{pH}$ via extended X-ray absorption fine structure (EXAFS) spectroscopy [27, 30-32]. DFOB coordinates to $\mathrm{Mn}(\mathrm{III})$ through the fully de-protonated hydroxamate ligands, while the terminal amine remains protonated, giving the complex an overall positive charge [27]. EXAFS fits reveal a Jahn-Teller distorted octahedral geometry wherein the first coordination shell is best split into two distinct environments, one consistent with two elongated axial oxygen atoms and the other with four equatorial oxygen atoms [32].

DFOB also dissolves manganite $(\gamma-\mathrm{MnOOH})$ through both reductive and non-reductive pathways, depending on $\mathrm{pH}[31]$. Above $\mathrm{pH} 6.5$ the formation of $\mathrm{Mn}(\mathrm{III})-\mathrm{HDFOB}^{+}$is observed, while below pH 6.5 aqueous $\mathrm{Mn}(\mathrm{II})$ is observed, indicating a reductive pathway, perhaps through oxidation of DFOB by $\mathrm{Mn}(\mathrm{III})$, similar to the irreversible decomposition of the Mn(III)$\mathrm{HDFOB}^{+}$seen below pH 7.1 [27, 31]. Dissolution by DFOB was observed for synthetic and biogenic $\mathrm{Mn}(\mathrm{IV})$-type oxides through a reductive pathway, and hausmannite $\left(\mathrm{Mn}_{3} \mathrm{O}_{4}\right)$ through pH-dependent reductive and non-reductive pathways, similar to manganite [31, 33, 34]. Adsorption of $\mathrm{Fe}$ (III) from $\mathrm{Fe}(\mathrm{III})-\mathrm{HDFOB}^{+}$was also observed in the case of the synthetic and biogenic Mn(IV) type oxides [35]. Because of the ability to bind and dissolve a variety of 
Edited Mar 14

minerals, siderophores may play an important role in biogenic cycling of manganese, in addition to iron, and possibly other metals [36-39].

Many other hydroxamate ligands, including other siderophores, such as coprogen, bind to $\mathrm{Mn}(\mathrm{II})$ and promote oxidation to $\mathrm{Mn}(\mathrm{III})[40,41]$. Coprogen (DFC) (Figure 1) is a trishydroxamate siderophore that binds $\mathrm{Fe}(\mathrm{III})$ and $\mathrm{Mn}$ (III) in a hexadentate octahedral coordination similar to DFOB and promotes the oxidation of bound Mn(II) to Mn(III) [40]. Stability constants for Fe(III)-DFC $\left(\log \beta_{110}=30.2\right)$ and $\mathrm{Mn}(\mathrm{III})-\mathrm{DFC}\left(\log \beta_{110}=28.1\right)$ are both quite high and consistent with the stability constants of other hydroxamic acid siderophores with both $\mathrm{Mn}(\mathrm{III})$ and $\mathrm{Fe}(\mathrm{III})[40,42]$.

\subsection{Pyoverdin-type Siderophores}

Pyoverdin-type siderophores were originally isolated from the pseudomonad bacterial family [43]. While pyoverdin (Figure 2) is a known Fe(III) chelator and is part of a well-studied microbial iron acquisition system, two of its derivatives, pyoverdin $\mathrm{PaA}\left(\mathrm{PVD}_{\mathrm{PaA}}\right)$ and pyoverdin Gb1 (PVD $\mathrm{Gb}_{\mathrm{G}}$ ) (Figure 2), have higher stability constants for $\mathrm{Mn}(\mathrm{III})$ than Fe(III) [28]. The stability constant for $\mathrm{Mn}(\mathrm{III})-\mathrm{PVD}_{\mathrm{PaA}^{-}}{ }^{-}$was determined by spectrophotometric competition between an iron(III)-citrate complex and $\mathrm{Mn}(\mathrm{III})-\mathrm{PVD}_{\mathrm{PaA}}{ }^{-}$and between $\mathrm{Fe}(\mathrm{III})-\mathrm{PVD}_{\mathrm{PaA}}{ }^{-}$and a manganese(III)-citrate complex (Equation 2) to approach the equilibrium state from both directions [28].

$$
\text { "Fe(III)-citrate" + Mn(III)-PVD } \mathrm{PaA}^{-}=\mathrm{Fe}(\mathrm{III})-\mathrm{PVD}_{\mathrm{PaA}}{ }^{-}+\text {"Mn(III)-citrate" }
$$

The speciation of the ferric and manganic citrate complexes was not described [28], and thus is presented in quotes in Equation 2. The stability constant for $\mathrm{Mn}(\mathrm{III})-\mathrm{PVD}_{\mathrm{PaA}}{ }^{-}, \log \beta_{110}=35.4 \pm$ 0.2, is more than five orders of magnitude higher than the ferric complex, $\mathrm{Fe}(\mathrm{III})-\mathrm{PVD}_{\mathrm{PaA}^{-},}, \log$ 
Edited Mar 14

$\beta_{110}=30.0$ for $[28,44]$. Similarly, the stability constant for $\mathrm{Mn}(\mathrm{III})-\mathrm{PVD}_{\mathrm{Gb} 1}\left(\log \beta_{110}=35.3\right)$ is higher than $\mathrm{Fe}(\mathrm{III})-\mathrm{PVD}_{\mathrm{Gb} 1}\left(\log \beta_{110}=31.06\right)[28,45,46]$.

The Mn(III)-pyoverdine complexes are consistent with a Jahn-Teller distorted octahedral geometry at $\mathrm{Mn}(\mathrm{III})$, as would be expected for a high spin $\mathrm{d}^{4}$ electronic configuration [28]. The best fit to the EXAFS data for the Mn(III)-pyoverdine complexes is consistent with splitting the first coordination shell into two distinct shells, one with two oxygen atoms in the axial positions and one with four oxygen atoms in the equatorial positions, similar to $\mathrm{Mn}(\mathrm{III})$-desferrioxamine B. The observed preference of these pyoverdines for $\mathrm{Mn}(\mathrm{III})$ may be due to conformational changes in the $\mathrm{PVD}_{\mathrm{Gb} 1}$ and $\mathrm{PVD}_{\mathrm{PaA}}$ backbone which could better accommodate the Jahn-Teller elongation of the axial positions, consistent with high spin $\mathrm{d}^{4}$ octahedral $\mathrm{Mn}(\mathrm{III})$ complexes. Production of $\mathrm{PVD}_{\mathrm{GB} 1}$ along with other PVD-type siderophores have been linked to regulation of $\mathrm{MnO}_{2}$ formation and biofilm production [47, 48].

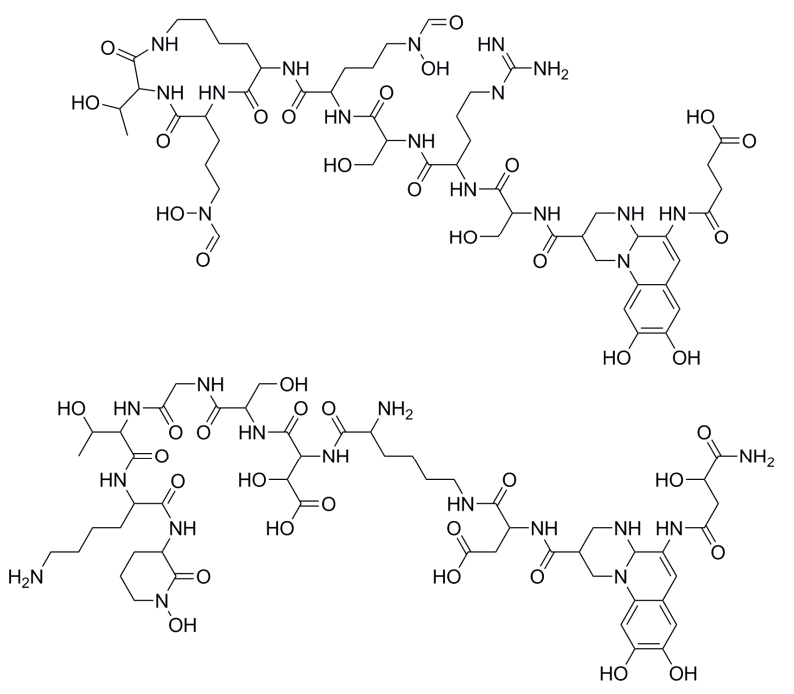

Figure 2: Pyoverdine PaA (top), pyoverdine Gb1 (bottom)

\subsection{Rhizoferrin}


Edited Mar 14

Rhizoferrin (Figure 3) is a siderophore produced by the fungus Rhizopus arrhizus and by the bacterium Ralstonia picketti $[49,50]$. Although the composition of rhizoferrin from these two sources is the same, the stereochemistry at the chiral quaternary centers is R,R in the case of the fungal Rhizopus siderophore and S,S for the R. picketti siderophore[50]. Iron(III) coordination occurs through both $\alpha$-hydroxy carboxylate moieties and pendant carboxylate moieties $[49,50]$, with a stability constant of $\log \beta_{110}=25.3$ for Fe(III)-Rhiz ${ }^{3-}$ [51]. Rhizoferrin also coordinates $\mathrm{Mn}(\mathrm{II})$ and $\mathrm{Mn}(\mathrm{III})[28,51]$. The stability constant of Mn(II)-Rhiz ${ }^{4-}$, determined by potentiometric titration, is $\log \beta_{110}=5.95 \pm 0.09$ [28]. The stability constant of $\mathrm{Mn}(\mathrm{III})-\mathrm{Rhiz}^{3-}$, determined by redox titration and calculated using a modified Nernst equation is $\log \beta_{110}=29.8 \pm 0.3$ [52], which is substantially higher than the Fe(III) complex. The authors suggest the higher stability constant for $\mathrm{Mn}(\mathrm{III})$ may reflect, in part, a stronger interaction of Mn(III) with the hydroxyl on the $\alpha$-hydroxy carboxylate moieties, as a result of the higher acidity of $\mathrm{Mn}(\mathrm{III})\left(\mathrm{pK}_{\mathrm{a}}\right.$ of $\left.\mathrm{Mn}\left(\mathrm{H}_{2} \mathrm{O}\right)_{6}{ }^{3+} \sim 0\right)$ over $\mathrm{Fe}(\mathrm{III})\left(\mathrm{pK}_{\mathrm{a}}\right.$ of $\left.\mathrm{Fe}\left(\mathrm{H}_{2} \mathrm{O}\right)_{6}{ }^{3+} \sim 2.7\right)[28,51,53]$, although pendant monodentate carboxylate ligation in the axial position (Figure 3) may best accommodate the Jahn-Teller distortion observed by EXAFS of the Mn(III)-Rhiz ${ }^{3-}$ complex [28], in a manner that is not possible with tris bidentate hydroxamate, $\alpha$-hydroxy carboxylate and catecholate ligands. 

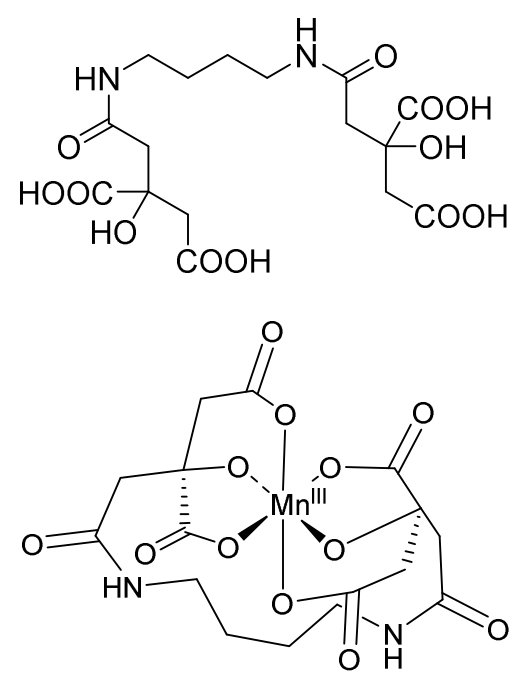

Figure 3: Rhizoferrin and Mn(III) complex depicting Jahn-Teller axial elongation

\subsection{Protochelin}

The tris catechol siderophore protochelin (Figure 6), which is covered below for its role in molybdenum and vanadium acquisition in the nitrogenase-producing bacterium Azotobacter vinlandii, also coordinates manganese. The Mn(III)-Proto ${ }^{3-}$ stability constant, $\log \beta_{110}$, is 41.6 which is lower than the Fe(III)-Proto ${ }^{3-}$ stability constant of $\log \beta_{110}$ at 44.6 [54]. While EXAFS data are best fit with four shorter Mn-O equatorial ligands and two longer Mn-O axial ligands, the instability of this complex prompted DFT investigations, which were also consistent with Jahn-Teller distortion at $\mathrm{Mn}$ (III). A shift from bidentate catecholate coordination to Fe(III) to salicylate coordination is often observed in catecholamide siderophores, as the $\mathrm{pH}$ is lowered $[54,55]$. However, the salicylate shift is not observed for Mn(III)-Proto ${ }^{3-}$; instead precipitation is observed below pH 6. $\mathrm{Mn}(\mathrm{III})-$ Proto $^{3-}$ reduction to $\mathrm{Mn}(\mathrm{II})$ may also occur [54]. 
Edited Mar 14

\section{Table 1}

Selected siderophore/chalkophore stability constants

\begin{tabular}{|c|c|c|c|c|c|c|}
\hline Siderophore & $\begin{array}{c}\mathrm{Mn}(\mathrm{III}) \\
\log \beta_{110}\end{array}$ & Ref. & $\begin{array}{l}\mathrm{Fe}(\mathrm{III}) \\
\log \beta_{110}\end{array}$ & Ref. & $\begin{array}{l}\mathrm{Cu}(\mathrm{I}) \\
\operatorname{LogK}_{\mathrm{b}}\end{array}$ & Ref. \\
\hline DFOB & $29.9 \pm 0.5$ & [27] & 30.6 & [29] & & \\
\hline Coprogen & 28.1 & [40] & 30.2 & [42] & & \\
\hline PVD-PaA & $35.4 \pm 0.2$ & [28] & 30.0 & [44] & & \\
\hline PVD-GB-1 & 35.3 & [28] & 31.06 & [28] & & \\
\hline Rhizoferrin & $29.8 \pm 0.3$ & [28] & 25.3 & [51] & & \\
\hline Protochelin & $41.6 \pm 0.3$ & [54] & 44.6 & [56] & & \\
\hline $\mathrm{Mb}-\mathrm{Ob} 3 \mathrm{~b}$ & & & & & 20.8 & [57] \\
\hline Mb-Strain M & & & & & 21.2 & [58] \\
\hline $\mathrm{Mb}-\mathrm{CSC} 1$ & & & & & 21.1 & [58] \\
\hline Mb-Rosea & & & & & 20.7 & [58] \\
\hline Mb-SB2 & & & & & $26.9 \pm 9.0$ & [59] \\
\hline
\end{tabular}

\section{Copper Complexation by Chalkophores and Siderophores}

Copper plays an important role in many biological systems, primarily in redox active metal centers. Certain bacteria have a high demand for copper, such as the majority of methanotrophs that express the particulate copper methane monooxygenase (pMMO). Methanotrophs are Gram-negative bacteria that grow on $\mathrm{CH}_{4}$ oxidation as their sole carbon source. Recently a family of copper-binding chelating agents have been discovered to be produced by methanotrophs. These ligands are usually referred to as methanobactins, but may also be called chalkophores, which derives from their affinity for copper and the Greek word "chalko" for copper. 
Edited Mar 14

\subsection{Methanobactins}

The first methanobactin to be discovered was isolated from the methanotroph Methylosinus trichosporium OB3b (Mb-OB3b; Figure 4), which also produces the coppercontaining pMMO if sufficient copper is available, or the iron-containing soluble MMO (sMMO) when copper is not available [60]. Methanobactins preferentiality bind $\mathrm{Cu}(\mathrm{I})$ in a distorted tetrahedral geometry through the nitrogen atoms contained in the two oxazolone rings and two thioamide sulfur atoms $[57,61]$. While methanobactin can coordinate $\mathrm{Cu}(\mathrm{II})$, it is quickly reduced to $\mathrm{Cu}(\mathrm{I})$ through an unknown mechanism [62-66]. The stability constant for $\mathrm{Cu}(\mathrm{I})-(\mathrm{Mb}-\mathrm{OB} 3 \mathrm{~b})$, established by competition with bathocuproine di-sulfonate (BCS) with equilibration established from both directions (i.e., from $\mathrm{Cu}(\mathrm{I})-\mathrm{Mb}+\mathrm{BCS}$ and $\left[\mathrm{Cu}(\mathrm{BCS})_{2}\right]^{3-}+$ apo-Mb) is $\log \mathrm{K}=20.8$ [57]. Uptake of $\mathrm{Cu}(\mathrm{I})-\mathrm{Mb}$ was demonstrated through isotopic and fluorescent labeling by $M$. trichosporium $\mathrm{OB} 3 \mathrm{~b}$, as well as by several other strains of methanotrophs, to occur via an active-transport process[67]. Methanobactins can coordinate a variety of different metal ions, but preferentially bind $\mathrm{Cu}(\mathrm{I})$ or $\mathrm{Cu}(\mathrm{II})$, and can displace $\mathrm{Fe}(\mathrm{III})$ from $\mathrm{Mb}$ [68, 69]. 


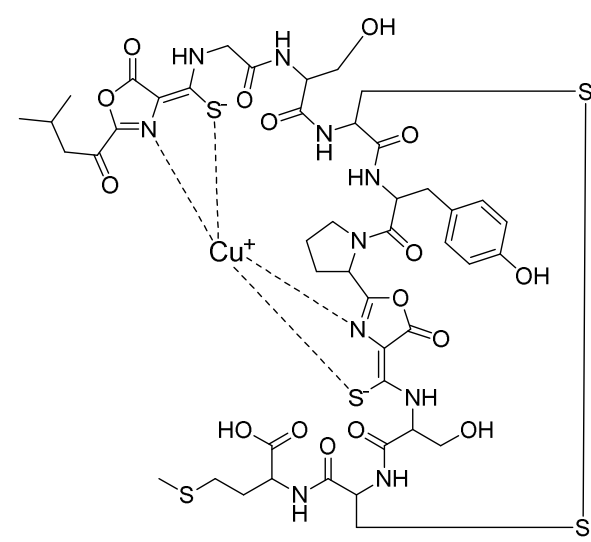

Methanobactin from $M$. trichosporium ОВ3b (Mb-OB3b))

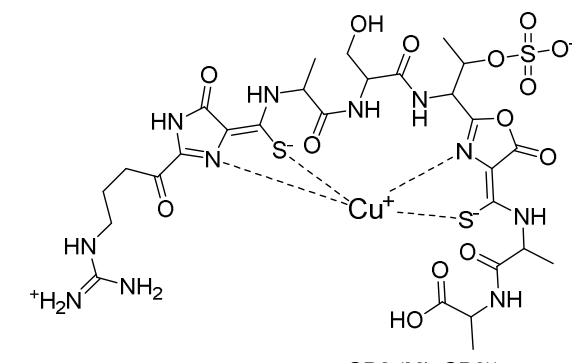

Methanobactin from Methylocystis SB2 (Mb-SB2))

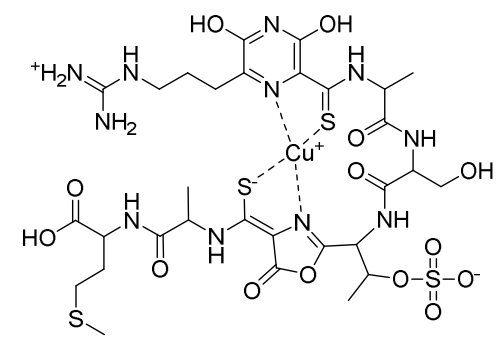

Methanobactin from Methylocystis strain M

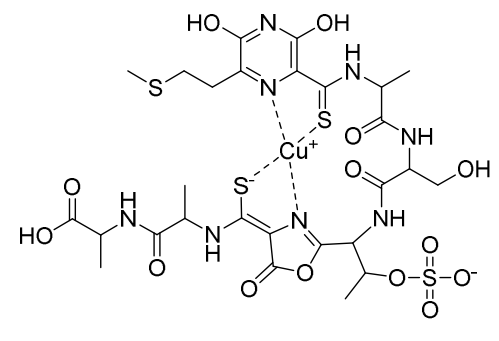

Methanobactin from Methylocystis hirsuta CSC1

Figure 4: Selected methanobactins.

Other methanotrophs (e.g., Methylococcus capsulatus Bath and Methylomicrobium album BG8, Methylocystis strain M, Methylocystis hirsuta CSC1, Methylocystis rosea, Methylocystis SB2, etc) produce methanobactins with structures and copper affinities similar to Mb-OB3b (Figure 4;

Table 1) [58, 69-71]. The $\mathrm{Cu}(\mathrm{I})$ affinity for the Methylococcus capsulatus Bath and Methylomicrobium album BG8 methanobactins were much lower than for Mb-OB3b [69]. Genome mining has recently been employed to search for other methanobactin type natural products in microbes, and has provided evidence that they may be more wide spread than previously thought [72].

\subsection{Yersiniabactin}

Yersiniabactin (Ybt; Figure 5) is a siderophore produced by pathogenic bacteria, such as Yersinia pestis and certain uropathogenic strains of E. coli [73-75]. It is now recognized that 


\section{Edited Mar 14}

both hosts and pathogens vary copper levels at sites of infections [76]. While mammalian hosts often increase $\mathrm{Cu}$ levels in response to a bacterial infection, the ability of a pathogen to resist the toxic effects of $\mathrm{Cu}$ determines its survival. Uropathogenic strains of E. coli secrete Ybt, not only for $\mathrm{Fe}(\mathrm{III})$ uptke, but also to chelate $\mathrm{Cu}$ (II) as a protective strategy, minimizing the effectiveness of copper as an antimicrobial agent [75-77]. Both $\mathrm{Cu}(\mathrm{I})$ and $\mathrm{Cu}(\mathrm{II})$ have antibacterial properties, although $\mathrm{Cu}(\mathrm{I})$ is considered to be significantly more bactericidal [77].

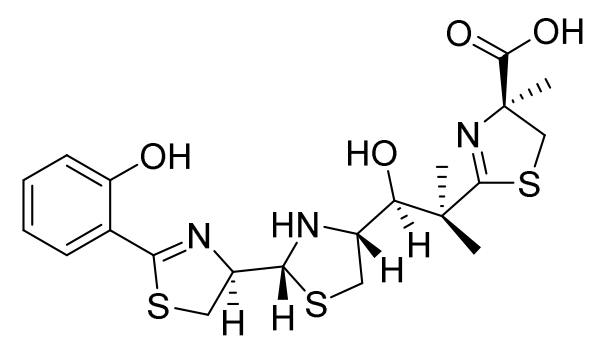

Figure 5: Yersiniabactin

The $\mathrm{Cu}(\mathrm{II})-\mathrm{Ybt}$ complex could also provide pathogens protection from the human immune response by mimicking superoxide dismutase activity (SOD) [75, 78]. Having siderophore-based SOD activity may be advantageous over similar enzymatic chemistry because the thiazoline and thiazolidine rings are protease resistant and are therefore only slowly broken down by phagosomes [79].

Coordination of transition metal ions to $\mathrm{Ybt}$ is achieved by three nitrogen atoms, one from the thiazolidine ring and two from the thiazoline rings, and three oxygen atoms from a phenolate, a secondary alcohol, and the carboxylate, respectively [80]. While Ybt can bind other metals such as $\mathrm{Zn}(\mathrm{II})$ and notably $\mathrm{Fe}(\mathrm{III})$ in its role as an iron-transporting siderophore, $\mathrm{Cu}(\mathrm{II})$ Ybt is stable in the presence of $\mathrm{Fe}(\mathrm{III})$ and both $\mathrm{Fe}(\mathrm{III})-\mathrm{Ybt}$ and $\mathrm{Cu}(\mathrm{II})-\mathrm{Ybt}$ are present in infections at similar concentrations, indicating a possible dual function [77]. 
Edited Mar 14

4. Molybdenum and Vanadium Complexation by Siderophores

Most nitrogen-fixing bacteria must obtain molybdenum or vanadium, along with iron, to form the active site of nitrogenase [81]. Because of the importance of Mo and V, interest in the mechanism of acquisition of molybdenum and vanadium by Azotobacter vinelandii has focused on siderophores, which include aminochelin, azotochelin, protochelin, and azotobactin (Figure 6) $[82,83]$.

\subsection{Protochelin and its Derivatives}

Protochelin, azotochelin, and aminochelin (Figure 6) are catechol siderophores that may be regulated by both molybdenum and iron concentrations $[82,84]$. Duhme et al showed that when iron and molybdenum are both limited in the growth medium, both aminochelin and azotochelin are produced. As the molybdenum concentration is increased in the growth medium, protochelin is preferentially produced $[85,86]$. In a separate study, however, Kraepiel et al have seen that protochelin is produced under most conditions $[87,88]$. They also observe reduced production of both protochelin and azotochelin under high molybdenum or vanadium concentrations and uptake of Mo siderophore complexes is shut down under high molybdenum concentrations $[87,88]$. While protochelin coordinates to both $\mathrm{Fe}(\mathrm{III})$ and $\mathrm{MoO}_{4}{ }^{2-}$, the molybdenum species appears to be kinetically favored, leading to higher concentration in the supernatant during the lag phase and initial exponential growth phases, while the iron species dominates thereafter [89].

The stability constant for $\mathrm{MoO}_{2}$-Azoto ${ }^{3-}(\mathrm{LogK}=35)$ was determined spectrophotometrically by direct titration of apo-azotochelin with sodium molybdate [85]. Coordination of molybdate $\left(\mathrm{MoO}_{4}{ }^{2-}\right)$ by azotochelin occurs through both catechol groups. The octahedral Mo(VI) center is filled out with two oxo ligands [90]. In addition to $\mathrm{MoO}_{4}{ }^{2-}$, 


\section{Edited Mar 14}

protochelin and azotochelin also coordinate vanadate, $\mathrm{VO}_{4}{ }^{3-}$, and tungstate, $\mathrm{WO}_{4}{ }^{2-}$. Protochelin coordinates $\mathrm{VO}_{4}{ }^{3-}$ which promotes uptake of vanadium by $A$. vinelandii $[87,88,91]$, for presumable incorporation into the alternative nitrogenase. Protochelin also coordinates $\mathrm{WO}_{4}{ }^{2-}$, and in fact high $\mathrm{WO}_{4}{ }^{2-}$ levels dramatically increases production of protochelin [92] presumably for protective purposes since $\mathrm{WO}_{4}{ }^{2-}$ is toxic to cell growth; minimal uptake of the $\mathrm{W}(\mathrm{VI})$ protochelin complex is observed compared with the Mo(VI)-protochelin complex [92]. Further A. vinelandii mutants deficient in catechol siderophore production are much more sensitive to tungstate levels in the environment than wild type $A$. vinelandii.
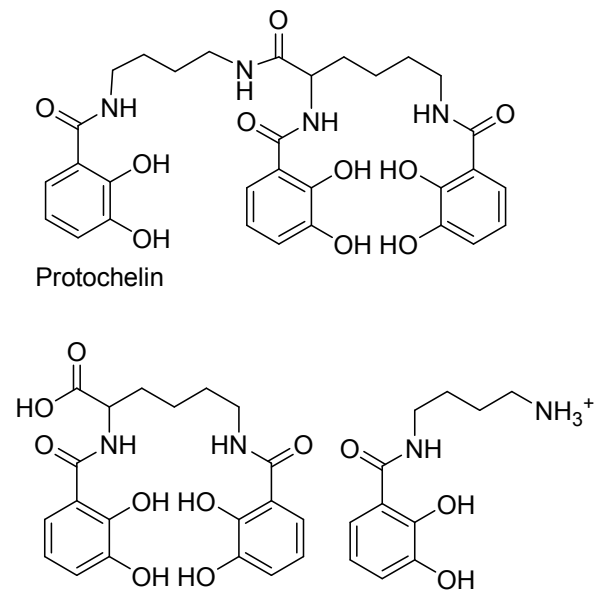

Azotochelin Aminochelin

Figure 6: Catechol siderophores from A. vinlandii

\subsection{Azotobactin}

Azotobactin (Figure 7) is a pyoverdine-type siderophore released in iron limited conditions by $A$. vinelandii [93-95]. In addition to $\mathrm{Fe}(\mathrm{III})$, azotobactin binds $\mathrm{MoO}_{4}{ }^{2-}$ and $\mathrm{VO}_{4}{ }^{3-}$ and the resulting complexes are taken up by the bacterium, presumably for incorporation into nitrogenase [96]. Although the binding affinity is much lower for $\mathrm{MoO}_{4}{ }^{2-}$ and $\mathrm{HVO}_{4}{ }^{2-} / \mathrm{H}_{2} \mathrm{VO}_{4}{ }^{-}$ than Fe(III), the binding of oxoanions may be kinetically favored due to their solubility when 


\section{Edited Mar 14}

competing for complexation with iron oxide minerals [96], allowing for azotobactin to deliver Mo(VI) and V(V), as well as Fe(III), to the bacterium [96]. Recently it was shown that Mo promotes the expression and buildup of azotobactin during growth of $A$. vinlandii supplemented by $10 \mu \mathrm{M} \mathrm{MoO}_{4}{ }^{2-}[82]$.

A. vinelandii is an interesting example of a bacterium which has high demands for multiple metal cofactors and utilizes the interplay of different small molecule metal chelators to facilitate uptake of required metal ions. Even in the case of varying metal concentration in the environment, $A$. vinelandii can obtain the iron, molybdenum, and/or vanadium it needs to grow and fix dinitrogen.

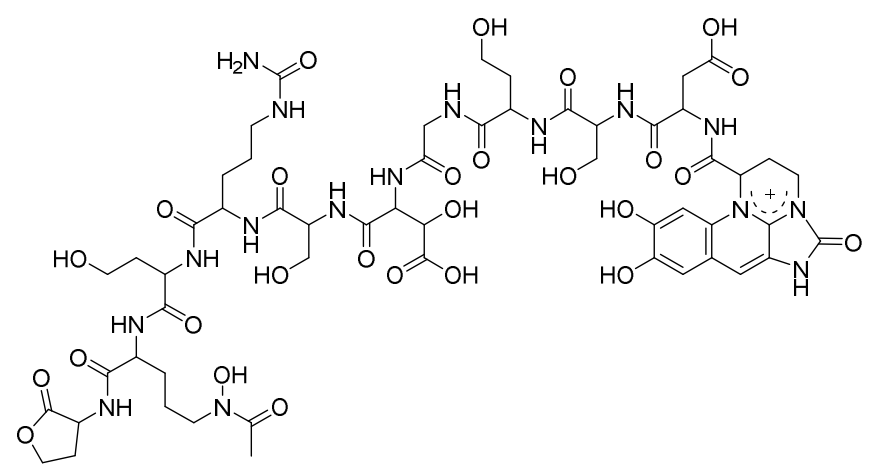

Figure 7: Azotobactin $\delta$ from A. vinelandii

\section{Summary}

While the vast majority of siderophores are involved in microbial iron acquisition, this review describes siderophores which complex transition metal ions other than iron under physiological conditions. In some cases, the siderophores promote bacterial uptake of these metal ions. Table 1 shows that siderophores with a wide variety of coordinating ligands all have appreciable stability constants for $\mathrm{Mn}(\mathrm{III})$, and several siderophores, e.g., $\mathrm{PVD}_{\mathrm{Gb} 1}, \mathrm{PVD}_{\mathrm{PaA}}$ and rhizoferrin, coordinate $\mathrm{Mn}(\mathrm{III})$ with higher affinity than Fe(III). For copper, a new class of microbial ligands 


\section{Edited Mar 14}

known as methanobactins or chalkophores, have been discovered recently. Genomics predictions suggest chalkophores may be quite common, although to date relatively few have been isolated and structurally characterized. The discovery and characterization of more chalkophores will be quite exciting, including their metal selectivities. Speculation on siderophore-mediated uptake of molybdenum and vanadium has persisted for many decades without conclusive evidence, until recently. Siderophores with only two bidentate ligands, such as the bis-catechol siderophore azotochelin, would seem to be ideal for Mo(VI) and V(V) given the propensity for cis-dioxo or cis oxo-hydroxo coordination in aqueous solution. Molybdate and vanadate uptake assisted by siderophores has now been established, although uncovering the pathways that must govern the competitive uptake of $\mathrm{Fe}(\mathrm{III})$ and $\mathrm{Mo}(\mathrm{V})$ (or V(V)) will be interesting. Hydroxamate ligands have been used for over a century in colorimetric spot tests to detect $\mathrm{Mo}(\mathrm{VI})$ and $\mathrm{V}(\mathrm{V})$, thus hydroxamate-siderophore complexation to these oxyanions is a topic of current interest [97, 98]. Putrebactin [99], alcaligin and bisucaberin are all cyclic siderophores with only two hydroxamic ligands, and thus should be good ligands for oxyanions, permitting cis-dioxo or cis-oxo-hydroxo coordination at the metal center. Putrebactin and DFOB bind vanadate and molybdate producing an array of structures varying in nuclearity and state of protonation, depending on the oxoanion concentration and $\mathrm{pH}$ [97]. While coordination chemists have been intrigued with coordination of many transition metal ions to siderophores since their initial discovery, future developments to investigate the biological occurrence of ligand-mediated uptake of transition metals other than iron or the expression of ligands to binds metals in virulence strategies will be especially interesting.

\section{$\underline{\text { Acknowledgement }}$}


Edited Mar 14

Funding from National Science Foundation Grant CHE-1411941 (A.B.) is gratefully

acknowledged. We wish Peter Ford many more birthday celebrations!

\section{$\underline{\text { References }}$}

[1] D.M. Templeton, Molecular and cellular iron transport, Marcel Dekker, New York, 2002.

[2] J.H. Crosa, A.R. Mey, S.M. Payne, Iron Transport in Bacteria, American Society of Microbiology, 2004.

[3] P. Cornelis, S.C. Andrews, Iron uptake and homeostasis in microorganisms, Caister

Academic Press, Norfolk, UK, 2010.

[4] H. Boukhalfa, A.L. Crumbliss, BioMetals, 15 (2002) 325-339.

[5] K.N. Raymond, E.A. Dertz, S.S. Kim, Proc. Natl. Acad. Sci. U. S. A., 100 (2003) 3584-3588.

[6] T. Fukushima, B.E. Allred, A.K. Sia, R. Nichiporuk, U.N. Andersen, K.N. Raymond, Proc

Natl Acad Sci U S A, 110 (2013) 13821-13826.

[7] R.C. Hider, X.-L. Kong, Nat. Prod. Rep., 27 (2010) 637-657.

[8] S. Dhungana, A.L. Crumbliss, Geomicrobiol. J., 22 (2005) 87-98.

[9] J. Francis, J. Madinaveitia, H.M. Nacturk, G.A. Snow, Nature (London, U. K.), 163 (1949)

365-366.

[10] J.A. Garibaldi, J.B. Neilands, Nature (London, U. K.), 177 (1956) 526-527.

[11] I.G. O'Brien, F. Gibson, Biochim. Biophys. Acta, Gen. Subj., 215 (1970) 393-402.

[12] J.R. Pollack, J.B. Neilands, Biochem. Biophys. Res. Commun., 38 (1970) 989-992.

[13] S.M. Kraemer, J. Xu, K.N. Raymond, G. Sposito, Environ. Sci. Technol., 36 (2002) 12871291.

[14] H. Boukhalfa, S.D. Reilly, M.P. Neu, Inorg. Chem., 46 (2007) 1018-1026.

[15] S.W. Frazier, R. Kretzschmar, S.M. Kraemer, Environ. Sci. Technol., 39 (2005) 5709-5715.

[16] J. Leong, K.N. Raymond, J. Am. Chem. Soc., 97 (1975) 293-296.

[17] R.C. Hider, A.F. Drake, R. Kuroda, J.B. Neilands, Naturwissenschaften, 67 (1980) 136-139.

[18] E.A. Enyedy, I. Pocsi, E. Farkas, J. Inorg. Biochem., 98 (2004) 1957-1966.

[19] S.J. Smith, K.S. Hadler, G. Schenk, G.R. Hanson, N. Mitić, in, 2010, pp. 273-341.

[20] R.J. Pace, R. Stranger, S. Petrie, Dalton Trans., 41 (2012) 7179-7189.

[21] T.G. Spiro, J.R. Bargar, G. Sposito, B.M. Tebo, Acc. Chem. Res., 43 (2010) 2-9.

[22] R.R. Eady, Chem. Rev. (Washington, D. C.), 96 (1996) 3013-3030.

[23] U. Patel, M. Baxi, V. Modi, Current Microbiology, 17 (1988) 179-182.

[24] K.S. Johnson, Science (Washington, DC, U. S.), 313 (2006) 1896-1897.

[25] R.E. Trouwborst, B.G. Clement, B.M. Tebo, B.T. Glazer, G.W. Luther, III, Science

(Washington, DC, U. S.), 313 (2006) 1955-1957.

[26] K.M. Faulkner, R.D. Stevens, I. Fridovich, Arch. Biochem. Biophys., 310 (1994) 341-346.

[27] O.W. Duckworth, G. Sposito, Environ. Sci. Technol., 39 (2005) 6037-6044.

[28] J.M. Harrington, D.L. Parker, J.R. Bargar, A.A. Jarzecki, B.M. Tebo, G. Sposito, O.W.

Duckworth, Geochim. Cosmochim. Acta, 88 (2012) 106-119.

[29] K.N. Raymond, E.A. Dertz, in, American Society for Microbiology, 2004, pp. 3-17.

[30] O.W. Duckworth, J.R. Bargar, G. Sposito, Environ. Sci. Technol., 43 (2009) 343-349. 
[31] O.W. Duckworth, G. Sposito, Environ. Sci. Technol., 39 (2005) 6045-6051.

[32] O.W. Duckworth, J.R. Bargar, A.A. Jarzecki, O. Oyerinde, T.G. Spiro, G. Sposito, Mar. Chem., 113 (2009) 114-122.

[33] O.W. Duckworth, G. Sposito, Chem. Geol., 242 (2007) 497-508.

[34] J. Pena, O.W. Duckworth, J.R. Bargar, G. Sposito, Geochim. Cosmochim. Acta, 71 (2007) 5661-5671.

[35] O.W. Duckworth, J.R. Bargar, G. Sposito, Geochim. Cosmochim. Acta, 72 (2008) 33713380 .

[36] O.W. Duckworth, J.R. Bargar, G. Sposito, BioMetals, 22 (2009) 605-613.

[37] K. Wuttig, M.I. Heller, P.L. Croot, Environ. Sci. Technol., 47 (2013) 10257-10265.

[38] M.M. Akafia, J.M. Harrington, J.R. Bargar, O.W. Duckworth, Geochim. Cosmochim. Acta, 141 (2014) 258-269.

[39] S.M. Kraemer, O.W. Duckworth, J.M. Harrington, W.D.C. Schenkeveld, Aquat. Geochem., (2014) Ahead of Print.

[40] O. Szabo, E. Farkas, Inorg. Chim. Acta, 376 (2011) 500-508.

[41] E. Farkas, O. Szabo, P.L. Parajdi-Losonczi, G. Balla, I. Pocsi, J. Inorg. Biochem., 139 (2014) 30-37.

[42] G.B. Wong, M.J. Kappel, K.N. Raymond, B. Matzanke, G. Winkelmann, J. Am. Chem. Soc., 105 (1983) 810-815.

[43] S. Wendenbaum, P. Demange, A. Dell, J.M. Meyer, M.A. Abdallah, Tetrahedron Lett., 24 (1983) 4877-4880.

[44] A.-M. Albrecht-Gary, S. Blanc, N. Rochel, A.Z. Ocaktan, M.A. Abdallah, Inorg. Chem., 33 (1994) 6391-6402.

[45] H. Boukhalfa, S.D. Reilly, R. Michalczyk, S. Iyer, M.P. Neu, Inorg. Chem., 45 (2006) 56075616.

[46] D.L. Parker, G. Sposito, B.M. Tebo, Geochim. Cosmochim. Acta, 68 (2004) 4809-4820.

[47] S.-W. Lee, K. Geszvain, B.M. Tebo, D.L. Parker, Front Microbiol, 5 (2014) 301.

[48] D.L. Parker, S.-W. Lee, K. Geszvain, R.E. Davis, B.M. Tebo, C. Gruffaz, J.-M. Meyer, J.W. Torpey, Front Microbiol, 5 (2014) 202.

[49] M. Shenker, Y. Hadar, Y. Chen, Soil Sci. Soc. Am. J., 60 (1996) 1140-1144.

[50] M. Munzinger, K. Taraz, H. Budzikiewicz, H. Drechsel, P. Heymann, G. Winkelmann, J.M. Meyer, BioMetals, 12 (1999) 189-193.

[51] C.J. Carrano, H. Drechsel, D. Kaiser, G. Jung, B. Matzanke, G. Winkelmann, N. Rochel, A.M. Albrecht-Gary, Inorg. Chem., 35 (1996) 6429-6436.

[52] D. Kim, O.W. Duckworth, T.J. Strathmann, Geochim. Cosmochim. Acta, 73 (2009) 12971311.

[53] M.J. Sisley, R.B. Jordan, Inorg. Chem., 45 (2006) 10758-10763.

[54] J.M. Harrington, J.R. Bargar, A.A. Jarzecki, J.G. Roberts, L.A. Sombers, O.W. Duckworth, BioMetals, 25 (2012) 393-412.

[55] S.M. Cohen, M. Meyer, K.N. Raymond, J. Am. Chem. Soc., 120 (1998) 6277-6286.

[56] A.K. Duhme, R.C. Hider, H.H. Khodr, Chem. Ber./Recl., 130 (1997) 969-973.

[57] A. El Ghazouani, A. Basle, S.J. Firbank, C.W. Knapp, J. Gray, D.W. Graham, C. Dennison, Inorg. Chem., 50 (2011) 1378-1391.

[58] A. El Ghazouani, A. Basle, J. Gray, D.W. Graham, S.J. Firbank, C. Dennison, Proc Natl Acad Sci U S A, 109 (2012) 8400-8404. 
Edited Mar 14

[59] N. Bandow, V.S. Gilles, B. Freesmeier, J.D. Semrau, B. Krentz, W. Gallagher, M.T. McEllistrem, S.C. Hartsel, D.W. Choi, M.S. Hargrove, T.M. Heard, L.N. Chesner, K.M. Braunreiter, B.V. Cao, M.M. Gavitt, J.Z. Hoopes, J.M. Johnson, E.M. Polster, B.D. Schoenick, A.M. Umlauf, A.A. DiSpirito, Journal of inorganic biochemistry, 110 (2012) 72-82.

[60] H.J. Kim, D.W. Graham, A.A. DiSpirito, M.A. Alterman, N. Galeva, C.K. Larive, D. Asunskis, P.M.A. Sherwood, Science (Washington, DC, U. S.), 305 (2004) 1612-1615. [61] H.J. Kim, N. Galeva, C.K. Larive, M. Alterman, D.W. Graham, Biochemistry, 44 (2005) 5140-5148.

[62] D.W. Choi, C.J. Zea, Y.S. Do, J.D. Semrau, W.E. Antholine, M.S. Hargrove, N.L. Pohl, E.S. Boyd, G.G. Geesey, S.C. Hartsel, P.H. Shafe, M.T. McEllistrem, C.J. Kisting, D. Campbell, V. Rao, A.M. De la Mora, A.A. DiSpirito, Biochemistry, 45 (2006) 1442-1453.

[63] A.S. Hakemian, C.E. Tinberg, K.C. Kondapalli, J. Telser, B.M. Hoffman, T.L. Stemmler, A.C. Rosenzweig, J. Am. Chem. Soc., 127 (2005) 17142-17143.

[64] G.E. Kenney, A.C. Rosenzweig, ACS Chem. Biol., 7 (2012) 260-268.

[65] M.-L. Pesch, I. Christl, M. Hoffmann, S.M. Kraemer, R. Kretzschmar, J. Inorg. Biochem., 116 (2012) 55-62.

[66] R. Balasubramanian, A.C. Rosenzweig, Curr. Opin. Chem. Biol., 12 (2008) 245-249.

[67] R. Balasubramanian, G.E. Kenney, A.C. Rosenzweig, The Journal of biological chemistry, 286 (2011) 37313-37319.

[68] D.W. Choi, Y.S. Do, C.J. Zea, M.T. McEllistrem, S.-W. Lee, J.D. Semrau, N.L. Pohl, C.J. Kisting, L.L. Scardino, S.C. Hartsel, E.S. Boyd, G.G. Geesey, T.P. Riedel, P.H. Shafe, K.A. Kranski, J.R. Tritsch, W.E. Antholine, A.A. DiSpirito, J. Inorg. Biochem., 100 (2006) 21502161.

[69] D.W. Choi, N.L. Bandow, M.T. McEllistrem, J.D. Semrau, W.E. Antholine, S.C. Hartsel, W. Gallagher, C.J. Zea, N.L. Pohl, J.A. Zahn, A.A. Di Spirito, J. Inorg. Biochem., 104 (2010) 1240-1247.

[70] B.D. Krentz, H.J. Mulheron, J.D. Semrau, A.A. Dispirito, N.L. Bandow, D.H. Haft, S. Vuilleumier, J.C. Murrell, M.T. McEllistrem, S.C. Hartsel, W.H. Gallagher, Biochemistry, 49 (2010) 10117-10130.

[71] B.S. Baral, N.L. Bandow, A. Vorobev, B.C. Freemeier, B.H. Bergman, T.J. Herdendorf, N. Fuentes, L. Ellias, E. Turpin, J.D. Semrau, A.A. DiSpirito, J. Inorg. Biochem., 141 (2014) 161169.

[72] G.E. Kenney, A.C. Rosenzweig, BMC Biol., 11 (2013) 17.

[73] A.M. Gehring, E. DeMoll, J.D. Fetherston, I. Mori, G.F. Mayhew, F.R. Blattner, C.T.

Walsh, R.D. Perry, Chem. Biol., 5 (1998) 573-586.

[74] H. Haag, K. Hantke, H. Drechsel, I. Stojiljkovic, G. Jung, H. Zaehner, J. Gen. Microbiol., 139 (1993) 2159-2165.

[75] K.S. Chaturvedi, C.S. Hung, D.E. Giblin, S. Urushidani, A.M. Austin, M.C. Dinauer, J.P. Henderson, ACS Chem. Biol., 9 (2014) 551-561.

[76] K.S. Chaturvedi, J.P. Henderson, Front. Cell. Infect. Microbiol., 4 (2014) 3/1-3/12.

[77] K.S. Chaturvedi, C.S. Hung, J.R. Crowley, A.E. Stapleton, J.P. Henderson, Nat. Chem. Biol., 8 (2012) 731-736.

[78] A. Paauw, M.A. Leverstein-van Hall, K.P. van Kessel, J. Verhoef, A.C. Fluit, PloS one, 4 (2009) e8240.

[79] C.T. Walsh, S.J. Malcolmson, T.S. Young, ACS Chem. Biol., 7 (2012) 429-442. 
[80] M.C. Miller, S. Parkin, J.D. Fetherston, R.D. Perry, E. DeMoll, J. Inorg. Biochem., 100 (2006) 1495-1500.

[81] Y. Hu, M.W. Ribbe, JBIC, J. Biol. Inorg. Chem., 19 (2014) 731-736.

[82] F. Yoneyama, M. Yamamoto, W. Hashimoto, K. Murata, J. Appl. Microbiol., 111 (2011) 932-938.

[83] A.M. Kraepiel, J.P. Bellenger, T. Wichard, F.M. Morel, Biometals : an international journal on the role of metal ions in biology, biochemistry, and medicine, 22 (2009) 573-581.

[84] K. Taraz, G. Ehlert, K. Geisen, H. Budzikiewicz, H. Korth, G. Pulverer, Z. Naturforsch., B: Chem. Sci., 45 (1990) 1327-1332.

[85] A.K. Duhme, R.C. Hider, M.J. Naldrett, R.N. Pau, JBIC, J. Biol. Inorg. Chem., 3 (1998) 520-526.

[86] A.S. Cornish, W.J. Page, BioMetals, 8 (1995) 332-338.

[87] J.P. Bellenger, T. Wichard, Y. Xu, A.M.L. Kraepiel, Environ. Microbiol., 13 (2011) 13951411.

[88] J.P. Bellenger, T. Wichard, A.B. Kustka, A.M.L. Kraepiel, Nat. Geosci., 1 (2008) 243-246, 243/241-243/249.

[89] M. Deicke, J.P. Bellenger, T. Wichard, J Chromatogr A, 1298 (2013) 50-60.

[90] J.-P. Bellenger, F. Arnaud-Neu, Z. Asfari, S.C.B. Myneni, E.I. Stiefel, A.M.L. Kraepiel, JBIC, J. Biol. Inorg. Chem., 12 (2007) 367-376.

[91] J.P. Bellenger, T. Wichard, A.M.L. Kraepiel, Appl. Environ. Microbiol., 74 (2008) 14781484.

[92] T. Wichard, J.-P. Bellenger, A. Loison, A.M.L. Kraepiel, Environ. Sci. Technol., 42 (2008) 2408-2413.

[93] O. Knosp, M. Von Tigerstrom, W.J. Page, J. Bacteriol., 159 (1984) 341-347.

[94] T. Palanche, S. Blanc, C. Hennard, M.A. Abdallah, A.-M. Albrecht-Gary, Inorg. Chem., 43 (2004) 1137-1152.

[95] W.J. Page, S.K. Collinson, P. Demange, A. Dell, M.A. Abdallah, Biol. Met., 4 (1991) $217-$ 222.

[96] T. Wichard, J.-P. Bellenger, F.M.M. Morel, A.M.L. Kraepiel, Environ. Sci. Technol., 43 (2009) 7218-7224.

[97] C.Z. Soe, A.A.H. Pakchung, R. Codd, Inorg. Chem., 53 (2014) 5852-5861.

[98] A.A.H. Pakchung, C.Z. Soe, T. Lifa, R. Codd, Inorg. Chem., 50 (2011) 5978-5989.

[99] K.M. Ledyard, A. Butler, J. Biol. Inorg. Chem., 2 (1997) 93-97. 
Edited Mar 14

Figure Captions

Figure 1: Selected hydroxamic acid siderophores

Figure 2: Pyoverdine $\mathrm{PaA}$ (top), pyoverdine Gb1 (bottom)

Figure 3: Rhizoferrin and Mn(III) complex depicting Jahn-Teller axial elongation

Figure 4: Selected methanobactins.

Figure 5: Yersiniabactin

Figure 6: Catechol siderophores from A. vinlandii

Figure 7: Azotobactin $\delta$ from A. vinelandii 